\title{
PENDIDIKAN ISLAM MULTIKULTUR: RELEVANSI, TANTANGAN, DAN PELUANG
}

\author{
Nuraliah Ali ${ }^{1)}$, Syamhudian Noor ${ }^{2)}$ \\ 1) Fakultas Hukum, Universitas Palangkaraya \\ email: lhy.alya.aly@gmail.com \\ ${ }^{2)}$ Fakultas Ilmu Sosial Politik, Universitas Palangkaraya \\ email: syamhudian@gmail.com
}

\begin{abstract}
This study aims to determine the relevance, challenges and opportunities of Multicultural Islamic education in Indonesia. This research type is a qualitative descriptive study with a religious and sociological approach. Research data obtained from in-depth interviews, document content and documentation will be processed through an interactive data analysis model from Mile \& Hubberman which consists of reduction, display, and verification / conclusion. The results of the study show that there is a match between multicultural values and educational value in an Islamic perspective such as democracy, tolerance, justice, equality, respecting differences and promoting human rights. The challenges and obstacles in formulating and adopting multicultural values in Islamic education are the inequality of perceptions of multicultural boundaries as an ideology, the ambiguity of tolerance limits that have the potential for ego-centricism, the choice of models and types of multicultural suitable for the Indonesian nation, the tendency for exclusivity in homogeneous groups, the feasibility and readiness of each component of the Islamic education system. Development of multicultural Islamic education has a great opportunity and relevance concepts value with Islamic education. The development of multiculturalbased Islamic education are response and answer to the challenges of diversity, modernization, globalization, solutions to the many conflicts and tensions that are patterned SARA in Indonesia and at the same time Multicultural Islamic education as a forum for cultural transfer between generations.
\end{abstract}

\section{Keywords: Education, Islamic, Multiculture.}

\begin{abstract}
Abstrak
Penelitian ini bertujuan untuk mengetahui relevansi, tantangan dan peluang pendidikan Islam Multikultural di Indonesia. Jenis penelitian ini adalah penelitian deskriptif kualitatif dengan pendekatan agama dan sosiologi. Data penelitian yang diperoleh dari wawancara mendalam, konten dokumen dan dokumentasi akan diolah melalui analisis data model interaktif dari Mile \& Hubberman yang terdiri dari langkah reduksi, tampilan, dan verifikasi/ kesimpulan. Adapun hasil penelitian diperoleh bahwa terdapat kesesuaian antara nilai multikultural dengan nilai pendidikan dalam perspektif Islam seperti demokrasi, toleransi, keadilan, kesetaraan, menghargai perbedaan dan menjungjung hak asasi manusia. Adapun tantangan dan hambatan dalam merumuskan dan mengadopsi nilai multikultural dalam pendidikan Islam adalah perbedaan persepsi batasan multikultural sebagai sebuah Ideologi, ambigunya batasan toleransi yang berpotensi pada ego-sentrisisme, pemilihan model dan jenis multikultur yang cocok untuk bangsa Indonesia, kecenderungan ekslusifitas pada kelompok homogen, kelayakan dan kesiapan setiap komponen-komponen dari
\end{abstract}


sistem pendidikan Islam. Pengembangan pendidikan Islam multikultur memiliki peluang yang besar dan masih sangat terbuka berdasarkan adanya relevansi dan inherensi konsep multikultural dalam pendidikan Islam. Pengembangan pendidikan Islam berbasis multikultur merupakan respon dan jawaban akan tantangan keragaman, modernisasi, globalisasi, solusi dari banyaknya konflik dan keteganganketegangan bermotif SARA di Indonesia dan sekaligus sebagai wadah pengalihan budaya antar generasi.

Keywords: Pendidikan, Islam, Multikultur.

\section{PENDAHULUAN}

Ditinjau dari sudut pandang historis, geografis dan sosial budaya, Indonesia merupakan salah satu negara yang memiliki struktur budaya yang beragam. Keragaman yang terbentuk merupakan akibat dari kondisi sosio kultural maupun geografis Indonesia yang begitu beragam dan luas. Secara geografis, Indonesia memiliki lebih dari 17. 000 pulau yang sebagian besar pulaunya dihuni oleh sekelompok manusia yang lebih lanjut membentuk masyarakat. Dari masyarakat tersebut terbentuklah sebuah kebudayaan dengan corak dan ragam khas masyarakat itu sendiri. Tentu saja hal ini berimbas pada keberadaan kebudayaan yang sangat banyak dan beraneka ragam meliputi etnis, ras, bahasa, budaya dan agama.

Keragaman etnis, ras, bahasa, budaya dan agama di Indonesia menimbulkan tantangan bagi sistem pendidikan untuk mengolah perbedaan-perbedaan itu menjadi potensi atau aset yang mengarah pada kemajuan yang baik atau positif, bukan justru menjadi sumber masalah dan konflik yang berkepanjangan. Di Indonesia misalnya beberapa waktu lalu, terjadi banyak kejadian dan fenomena sosial yang berawal dari perbedaan dan keragaman. Misalnya kasus dugaan penistaan agama yang gagal dipahami sebagai satu kesepahaman utuh sehingga seolah memecah masyarakat ke dalam kelompok-kelompok yang bertentangan dan berselisih paham/ pendapat, demo besar-besaran, tawuran antar daerah, dan berbagai kasus sosial lain yang berpotensi menjadi konflik yang berkepanjangan. Di sisi lain, ada apel kebangsaan yang mengingatkan NKRI sebagai bangsa yang bangga akan kemajemukan dan keragaman tetapi bisa hidup rukun di tengah perbedaan yang ada.

Permasalahan dan konflik yang muncul sebagai akibat dari keragaman menggambarkan bahwa keragaman selain menjadi potensi dan aset yang bernilai, keragaman juga dapat menjadi ancaman kesatuan dan persatuan bagi bangsa dan negara. Meskipun demikian, keragaman merupakan sebuah keniscayaan yang tidak terelakan dan tidak dapat ditolak dalam sebuah kelompok masyarakat. Melupakan 
keragaman merupakan tindakan kemunduran yang membawa masalah sosial. Maka, pemahaman mulkultural menjadi peluang dan solusi strategis yang membawa pendewasaan, bukan hanya pada masingmasing pribadi tetapi seluruh masyarakat itu sendiri demi terwujudnya pembangunan Indonesia ke arah yang lebih baik.

Salah satu bentuk pendidikan yang menawarkan kemampuan mengoordinasi dan mengakomodir perbedaan dan keanekaragaman yaitu pendidikan multikultural. Pendidikan multikultural adalah gerakan pembaruan dan inovasi pendidikan untuk menanamkan kesadaran akan pentingnya hidup bersama dalam keragaman dan perbedaan dan mampu menumbuhkan apresiasi terhadap perbedaan yang ada seperti budaya, ras, dan agama tanpa mengubah dan meninggalkan identitas mereka sendiri.

Sebagai bagian dari sistem pendidikan Nasional, pendidikan Islam juga dianggap perlu untuk menerapkan pendidikan yang tidak hanya fokus pada transfer pengetahuan saja tetapi juga mampu menanamkan semangat kehidupan beragama berdasarkan nilai-nilai toleransi, kebersamaan, kepedulian, kepedulian, perdamaian, persatuan, rasa hormat untuk perbedaan dan sikap lain yang menjunjung tinggi nilai kemanusiaan.
Secara teoritis, pendidikan Islam multikultural dianggap cocok untuk diterapkan pada kondisi bangsa yang struktur budayanya beragam seperti Indonesia. Namun, dalam perkembangannya tidak dapat disepakati dan diterima bersama oleh semua pihak, ada beberapa kelompok dan individu yang menentang penerapannya di Indonesia. Oleh karena itu, dipandang perlu untuk meneliti dan mengkaji mengenai Relevansi, Tantangan dan Peluang Penerapan Pendidikan Islam Multikultural di Indonesia. Adapun kontribusi dari studi penelitian ini adalah:

1. Teori. Sebagai sumbangsi pemikiran yang bersifat literal dalam memperkaya khazanah ilmu pengetahuan tentang pendidikan Islam Multikultural. Dengan adanya studi ini diharapkan dapat menjadi sebuah wacana pendidikan yang selanjutnya dapat menjadi sebuah teori untuk mendorong peningkatan kualitas pendidikan.

2. Praktis

a. Manfaat bagi Sistem Pendidikan Indonesia

1) Sebagai bahan pertimbangan dalam menerapkan suatu pendekatan baru dalam sistem pendidikan indonesia, khususnya bagaimana pendidikan Islam Multikultural diterapkan di lembaga-lembaga pendidikan. 
2) Diharapkan menjadi konsep pendidikan model baru agar dapat memperluas dan mempertajam konsep pendidikan yang telah ada saat ini.

b. Manfaat bagi Institusi pendidikan

1) Sebagai sumbangsi pemikiran dalam mengefektifkan pelaksanaan Pendidikan Islam yang mengakomodasi segala bentuk dinamika keagamaan dan perbedaan.

2) Sebagai referansi dalam menerapkan suatu model dan desain pembelajaran yang bertujuan agar peserta didik/mahasiswa memiliki kepekaan dalam menghadapi masalah-masalah dan gejala sosial yang berakar pada perbedaan suku, ras, agama dan tata nilai dalam masyarakat.

c. Manfaat Penulis/ peneliti

1) Sebagai sumber referensi atau literatur tambahan bagi peneliti selanjutnya.

2) Manfaat bagi pribadi penulis. Secara pribadi, Studi ini memiliki kontribusi yang sangat berharga yakni menambah wawasan sebagai pendidik sekaligus pengelola pendidikan yang bertanggungjawab dalam mengelola sebuah konsep, pendekatan, strategi dan desain pembelajaran yang ramah terhadap keragaman yang ada. Dengan banyaknya keragaman yang ada maka penting untuk memiliki pengetahuan yang mumpuni akan konsep dan pendekata baru agar mampu merumuskan suatu desain dan model Instruksional untuk mengakomodir perbedaan tersebut agar tidak terjadi konflik.

\section{KAJIAN TEORI}

\section{a. Multikulturalisme}

Multikultural secara sederhana dapat dikatakan pengakuan atas pluralisme budaya. Pluralisme budaya bukanlah suatu yang diberikan atau diperoleh begitu saja tetapi merupakan suatu proses internalisasi nilainilai di dalam suatu komunitas. Multikulturalisme berasal dari kata multi (plural) dan kultural (tentang budaya), multikulturalisme mengisyaratkan pengakuan terhadap realitas keragaman kultural, yang berarti melingkupi keberagaman tradisional seperti keberagaman suku, ras, ataupun agama, maupun keberagaman bentuk-bentuk kehidupan (subkultur) yang terus bermunculan di setiap tahap sejarah kehidupan masyarakat. Istilah 
multikulturalisme secara umum diterima secara positif oleh masyarakat Indonesia. Ini tentu ada kaitannya dengan realitas masyarakat Indonesia yang majemuk.

Akhiran "isme" atau paham dalam multikulturalisme menandakan suatu doktrin normatif yang diharapkan bekerja pada setiap orang dalam konteks masyarakat dengan beragam budaya. Proses dan cara bagaimana multikulturalisme sebagai doktrin normatif menjadi ada dan implementasi gagasangagasan multikultural yang telah dilakukan melalui kebijakan-kebijakan politis, dalam hal ini meliputi kebijakan-kebijakan pendidikan

Menurut Parekh (2001), ada tiga komponen multikulturalisme, yakni kebudayaan, pluralitas kebudayaan, dan cara tertentu untuk merespons pluralitas itu. Multikulturalisme bukanlah doktrin politik pragmatik, melainkan cara pandang kehidupan manusia. Karena hampir semua negara di dunia tersusun dari aneka ragam kebudayaan - artinya perbedaan menjadi asasnya-dan gerakan manusia dari satu tempat ke tempat lain di muka bumi semakin intensif, maka multikulturalisme itu harus diterjemahkan ke dalam kebijakan multikultural sebagai pengelolaan perbedaan kebudayaan warga negara.

\section{b. Pendidikan Multikultural}

Pendidikan multikultural, sejak lama telah berkembang di Eropa dan Amerika
Serikat. Strategi pendidikan multikultural adalah pengembangan dari studi interkultural dan multikulturalisme. Dalam perkembangannya, pendidikan multikultural ini justru menjadi motor penggerak dalam menegakkan demokrasi, humanisme dan pluralisme yang dilakukan melalui sekolah, kampus, dan institusi-institusi pendidikan lainnya seperti halnya yang terjadi di AS.

Secara teoritis dan praktiknya, Pendidikan multikultural sekarang sudah mengalami perkembangan. Tahun 1960-an konsep awal pendidikan multikultural pertama kali dikemukakan oleh Banks. Banks (2001) berpendapat bahwa pendidikan multikultural merupakan suatu rangkaian kepercayaan (set of beliefs) dan penjelasan yang mengakui dan menilai pentingnya keragaman budaya dan etnis di dalam bentuk gaya hidup, pengalaman sosial, identitas pribadi, kesempatan pendidikan dari individu, kelompok maupun negara. Ia mendefinisikan pendidikan multikultural adalah ide, gerakan, pembaharuan pendidikan dan proses pendidikan yang tujuan utamanya adalah untuk mengubah struktur lembaga pendidikan supaya anggota dari kelompok ras, etnis, dan kultur yang bermacam-macam itu akan memiliki kesempatan yang sama untuk mencapai prestasi akademis.

Adapun Howard (1993) berpendapat bahwa pendidikan multukultural memberi 
kompetensi multikultural. Pada masa awal kehidupan anak, waktu banyak dilalui di daerah etnis dan kulturnya masing-masing. Kesalahan dalam mentransformasi nilai, aspirasi, etiket dari budaya tertentu, sering berdampak pada primordialisme kesukuan, agama, dan golongan yang berlebihan. Faktor ini penyebab timbulnya permusuhan antar etnis dan golongan. Melalui pendidikan multikultural sejak dini diharapkan anak mampu menerima dan memahami perbedaan budaya yang berdampak pada perbedaan usage (cara individu bertingkah laku); folkways (kebiasaan-kebiasaan yang ada di masyarakat), mores (tata kelakuan di masyarakat), dan customs (adat istiadat suatu komunitas).

Menurut Farida Hanum (2005) dengan pendidikan multikultural peserta didik mampu menerima perbedaan, kritik, dan memiliki rasa empati, toleransi pada sesama tanpa memandang golongan, status, gender, dan kemampuan akademik. Hal senada juga ditekankan oleh Musa Asya'rie (2004) bahwa pendidikan multikultural bermakna sebagai proses pendidikan cara hidup menghormati, tulus, toleransi terhadap keragaman budaya yang hidup di tengahtengah masyarakat plural, sehingga peserta didik kelak memiliki kekenyalan dan kelenturan mental bangsa dalam menyikapi konflik sosial di masyarakat.

\section{c. Pendidikan Islam Multikultural}

Sistem pendidikan Islam di Indonesia merupakan bagian dari sistem pendidikan nasional Indonesia. Sebagaimana disebutkan dalam pasal 15 Undang-undang Sistem Pendidikan Nasional No.20 Tahun 2003, bahwa pendidikan formal termasuk pendidikan umum, pendidikan kejuruan, pendidikan khusus, pendidikan magang, pendidikan keagamaan, pendidikan akademik, dan pendidikan profesi.

Sebagai subsistem, pendidikan Islam mempunyai tujuan khusus yang harus dicapai, dan tercapainya tujuan tersebut akan menunjang pencapaian tujuan pendidikan nasional secara keseluruhan yang menjadi suprasistemnya (Dzakiya Drajat: 2000). Pendidikan Islam dituntut agar dapat mengakomodir keragaman yang ada di Indonesia. Bentuk pendidikan yang menawarkan kemampuan untuk mencapai dan mengoordinasi oriantasi tersebut melalui pendidikan Islam berbasis multikultur.

Pendidikan Islam multikultural juga dapat dipahami sebagai proses pendidikan yang berprinsip pada demokrasi, kesetaraan dan keadilan; berorientasi kepada kemanusiaan, kebersamaan, dan kedamaian; serta mengembangkan sikap mengakui, menerima dan menghargai keragaman berdasarkan al-Qur'an dan hadis.( Sangkot Sirait: 2010). Karena secara normatif, alQur'an sendiri sudah menegaskan bahwa manusia memang diciptakan dengan latar 
belakang yang beragam. Hal ini ditegaskan dalam QS. al-Hujurat:13

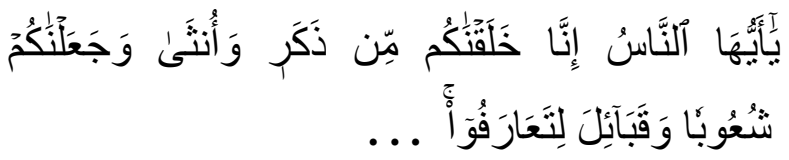

Terjemahnya:

"Hai Manusia, sesungguhnya Kami ciptakan kamu dari seorang laki-laki dan seorang perempuan dan menjadikan kamu berbangsa-bangsa dan bersuku-suku supaya kamu saling mengenal...".

Pendidikan multikultural dalam Islam dijadikan sebagai usaha yang dilakukan secara sadar untuk mengembangkan kepribadian yang mempelajari tentang berbagai macam status sosial, ras, suku, agama agar tercipta kepribadian yang cerdas dalam menghadapi masalah-masalah keberagaman budaya yang disesuaikan dengan nafas Islam sebagai sarana dalam mendekatkan diri pada Allah menuju makhluk yang mulia dengan taqwa. Oleh sebab itu, Rumusan tujuan akhir pendidikan Islam multikultural difahami sebagai jalan untuk membina dan memiliki karakter yang kuat untuk selalu bersikap demokratis, pluralis dan humanis. Karena tiga hal tersebut adalah ruh pendidikan multikultural (Qaimuddin, hal. 126).

\section{d. Relevansi penelitian sebelumnya}

Kajian mengenai pendidikan Islam berbasis multikultur merupakan objek studi yang menarik dan memiliki nilai kelayakan untuk dikaji. Terdapat beberapa penelitian sebelumnya yang relevan terhadap penelitian ini, diantaranya:

Penelitian yang dilakukan oleh Achmad Rois yang mengkaji "Pendidikan Islam Multikultural, Telaah Pemikiran Muhammad Amin Abdullah". Hasil penelitian ini menyatakan bahwa Pendidikan Islam Multikultural bertujuan menciptakan masyarakat madani yang menjunjung tinggi konsep social contract, yaitu sebuah konsep yang setiap individu dan kelompok memiliki hak dan kewajiban sama, meskipun mereka berada di bawah latar belakang yang berbeda. Urgensi pendidikan multikultural dalam pendidikan Islam menurut Amin Abdullah adalah membangun pemahaman beragama yang inklusif dan menciptakan kerukunan antarumat beragama. Pemikiran Amin Abdullah dalam sistem pendidikan Islam di Indonesia, cukup menonjol mulai dari gagasan integratif-interkonektif yang kemudian diaplikasikannya dalam pengembangan IAIN menjadi UIN Sunan Kalijaga.

Hasil penelitian Ahmad Rois ini menunjukan bahwa konsep Pendidikan Islam berbasis Multikultur dapat di implementasikan dan diadopsi oleh pendidikan di Indonesia, dengan pertimbangan bahwa pendidikan Islam multikultural menurut Amin Abdullah ikut memberi sumbangan wacana yang signifikan 
dalam menciptakan konsep-konsep observasi, tinjauan pustaka (content pendidikan Islam yang toleran, demokratis, document) dan dokumentasi. serta menjunjung tinggi nilai-nilai persatuan dan keadilan.

Penelitian selanjutnya oleh Anggi Anggara dengan judul "Urgensi Pendidikan Multikultural di Indonesia dalam Agama Islam". Hasil dari penelitian ini mengemukakan bahwa Indonesia sebagai negara dengan masyarakat multikultur memerlukan pendidikan agama yang sesuai dengan kondisi yang mampu menumbuhkan kesadaran berbudaya, sadar akan hadirnya berbagai perbedan kebudayaan dan kesatuan sosial, membina hubungan harmonis terhadap sesama manusia, menghargai perbedaan baik perbedaan keyakinan, suku, ras, dan perbedaan lainnya.

Kedua penelitian sebelumnya menunjukan bahwa kajian mengenai pendidikan Islam multikultur memiliki nilai lebih untuk dikaji lebih lanjut mengingat karakteristik pendidikan multikultur dapat mengakomodir dan menawarkan solusi teoritis dan praktis bagi keragaman dan kemajemukan bangsa Indonesia.

\section{METODE PENELITIAN}

Jenis penelitian ini adalah penelitian deskriptif kualitatif dengan pendekatan agama dan sosiologi. Metode penelitian yang akan digunakan dalam penelitian ini adalah wawancara mendalam (deepth interview), a. Wawancara mendalam (deepth interview).

Wawancara dilakukan kepada informan yang telah dipilih melalui teknik purposive sampling, secara terstruktur. Tujuan dari wawancara ini adalah untuk memperoleh informasi yang terperinci dan mendalam tentang pandangan informan tentang tantangan, relevansi dan strategi pengembangan pendidikan multikultural. Wawancara ini dilakukan pada informan yang dianggap dapat mencapai tujuan penelitian, seperti pengamat pendidikan, praktisi pendidikan dan manajer lembaga pendidikan yang mengadopsi pendidikan Islam multikultural dalam sistem pendidikan di lembaga mereka.

b. Tinjauan literatur atau konten dokument. Tinjauan literatur mengkaji berbagai literatur ilmiah, baik dalam bentuk buku, majalah, buletin, surat kabar, dan sebagainya yang terkait dengan masalah dalam penelitian ini Tinjauan literatur atau dokumen konten bertujuan untuk meneliti secara mendalam isi suatu informasi tentang informasi tantangan, relevansi dan strategi pengembangan pendidikan Islam multikultural yang ditulis atau dicetak di media massa dengan menggunakan 
teknik pengkodean simbol, perhatikan simbol atau pesan secara sistematis, kemudian diberikan interpretasi atau kesimpulan.

e. Dokumentasi

\section{Dokumentasi}

didefinisikan

sebagai segala bahan tertulis seperti buku, majalah, dokumen, peraturan, risalah rapat, foto kegiatan, buku harian dan lain-lain. Jelas dalam hal ini adalah catatan tertulis terkait penelitian pendidikan multikultural Islam.

\section{HASIL DAN PEMBAHASAN}

\section{a. Relevansi Pendidikan Multikultur di Indonesia}

Konsep mengenai relevansi antara pendidikan Islam dan pendidikan multikultur dapat dilihat dengan menyandingkan konsep, ide, pemikiran diantara keduanya. Dengan mengkaji hakikat, landasan, prinsip, bentuk dan karakteristik masing-masing, akan diperoleh pemahaman apakah paham multikultural dapat diimplementasikan atau relevan dengan pendidikan Islam. Oleh karena itu, pembahasan mengenai relevansi pendidikan Islam multikultur akan diawali dengan kajian hakikat pendidikan Islam dan hakikat pendidikan multikultur. Adapun karakteristik pendidikan Islam dan pendidikan Multikultural dapat dilihat pada tabel berikut:
Tabel 1: Karakteristik pendidikan Islam dan Pendidikan Multikultural

\begin{tabular}{|c|c|c|}
\hline $\begin{array}{c}\text { Karakteristi } \\
\mathbf{k}\end{array}$ & $\begin{array}{c}\text { Nilai } \\
\text { multikultur } \\
\text { al }\end{array}$ & $\begin{array}{c}\text { Nilai } \\
\text { pendidikan } \\
\text { Islam } \\
\end{array}$ \\
\hline Landasan & Filsafat & $\begin{array}{l}\text { Al Qur'an, } \\
\text { hadist, } \\
\text { Ijtihad }\end{array}$ \\
\hline $\begin{array}{l}\text { Acuan } \\
\text { pedagogig }\end{array}$ & $\begin{array}{l}\text { Persamaan } \\
\text { derajat, } \\
\text { kesetaraan } \\
\text { (Equalty) }\end{array}$ & $\begin{array}{l}\text { Fitrah } \\
\text { sederajat, } \\
\text { universal }\end{array}$ \\
\hline Prinsip & $\begin{array}{l}\text { Demokrasi, } \\
\text { pluralisme } \\
\text { dan keadilan }\end{array}$ & $\begin{array}{l}\text { Al- } \\
\text { Musyawara } \\
\text { h, al- } \\
\text { musawah } \\
\text { dan al-'adl }\end{array}$ \\
\hline Orientasi & $\begin{array}{l}\text { Kemanusiaan } \\
\text { kebersamaan, } \\
\text { dan } \\
\text { kedamaian }\end{array}$ & $\begin{array}{l}\text { Hablum min } \\
\text { an-nas, al- } \\
\text { ta'aruf, al- } \\
\text { ta'awun dan } \\
\text { al-salam }\end{array}$ \\
\hline $\begin{array}{l}\text { Pengembanga } \\
\text { n sikap }\end{array}$ & $\begin{array}{l}\text { Toleransi, } \\
\text { empati, } \\
\text { simpati, dan } \\
\text { solidaritas } \\
\text { sosial }\end{array}$ & $\begin{array}{l}\text { Al- } \\
\text { ta'addudiyat } \\
\text {, al- } \\
\text { tanawwu', } \\
\text { al-tasamuh, } \\
\text { al-rahmah, } \\
\text { al- 'afw dan } \\
\text { al-ihsan }\end{array}$ \\
\hline
\end{tabular}

Dengan memperhatikan uraian-uraian tentang karakteristik pendidikan Islam dan multikultural dapat dipahami bahwa terdapat kesesuaian antara nilai-nilai multikultural dengan nilai-nilai pendidikan dalam perspektif Islam. Meskipun demikian, sember kebenaran dari nilai-nilai multikultural tersebut berbeda. Jika nilai-nilai 
multikultural yang berasal dari barat perbedaan yang menjadi prinsip-prinsip bersumber dari filsafat dan bertumpu pada dari paham multikulturalisme pada hak-hak asasi manusia, maka nilai-nilai dasarnya telah diajarkan dan dicontohkan multikultural dalam perspektif Islam oleh Rasulullah SAW. Lebih lanjut bersumber dari wahyu. Berikut pembahasan menurut Ahdan S bahwa prinsip demokrasi karakteristik yang relevan antara yang menjadi cikal bakal lahirnya multikultural dan pendidikan Islam: multikultur di Amerika telah dipraktikkan Karakteristik pertama yakni oleh Rasulullah melalui piagam Madinah Demokrasi. Konsep demokrasi yang merupakan tonggak sejarah munculnya multikultural di Amerika dan kanada, telah dijelaskan dalam al Qur'an Q.S. ashShurah: 38 ,

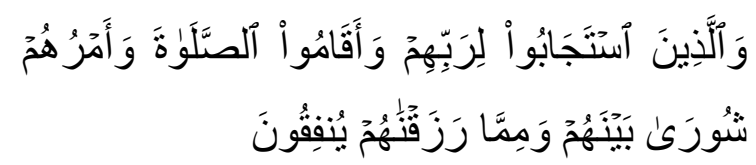

Terjemahnya:

"Dan (bagi) orang-orang yang menerima (mematuhi) seruan Tuhannya dan mendirikan salat, sedang urusan mereka (diputuskan) dengan musyawarah antara mereka; dan mereka menafkahkan sebagian dari rezki yang Kami berikan kepada mereka."

Meskipun berbeda landasan dan sumber hukum, pada hakikatnya karakteristik pendidikan Islam dan Multikultural memiliki kesamaan bahkan Islam sudah jauh lebih dahulu membahas mengenai konsep menghargai keragaman, pluralitas dan demokrasi. Hal ini sesuai dengan pernyataan ahdan S (wawancara: 2019) bahwa toleransi, keadilan, menghargai yang menjamin kelompok-kelompok masyarakat memperoleh status yang sama atau persamaan dalam kehidupan dan berhak atas jaminan asasinya (hidup dan harta) sebagai manusia.

Karakteristik kedua yaitu mengakui dan mengharai pluralitas. Pendidikan multikultural menerapkan prinsip pluralisme, sebagai konsekuensi logis bagi hakekat manusia. Artinya manusia selalu bersama dengan segala perbedaanperbedaan dan keragaman dan pluralitas bukan dijadikan sebagai potensi kerusuhan, melainkan merupakan potensi untuk diajak bersama melaksanakan ajaran demi kepentingan kemanusiaan. Maka pengembangan sikap toleransi merupakan upaya strategis yang bisa dilakukan, yakni dengan menghormati orang atau golongan lain tanpa kehilangan identitas diri. Maka menghargai perbedaan adalah salah satu sikap yang harus dikembangkan dalam rangka mewujudkan pendidikan multikultural (Moh. Miftahul Choiri: 2003). 
Pendidikan Islam sendiri memandang pluralisme tidak bertentangan dengan Islam, bahkan Islam memberikan kerangka sikap etis dan positif. Sikap etis dan positif Islam dimaksud tercermin dari beberapa ayat alQur'an yang secara eksplisit mengakui kenyataan tersebut. Seperti al-Qur'an menyatakan bahwa manusia diciptakan berbangsa-bangsa dan bersuku-suku agar mereka saling mengenal dan menghargai (QS. Al-Hujurat: 13). Al-qur'an juga menyatakan bahwa perbedaan di antara manusia dalam bahasa dan warna kulit harus diterima sebangai kenyataan positif sebagai satu di antara tanda-tanda kekuasaan Allah QS. Ar-Rum: 22. Pendidikan Islam memiliki kaitan hubungan dengan konteks yang melingkupinya, salah satunya adalah keanekaragaman jenis kelamin, ras, agama, budaya dan lain Jadi prinsip pendidikan Islam yang berdasarkan al-Qur'an dan hadits tidak menafikan perbedaan keragaman, justru pendidikan Islam melihat sebagai sebuah "rahmat" yang bisa bernilai positif.

Karakteristik ketiga yakni keadilan. Selain menghargai pluralitas, kesamaan karakteristik juga dapat ditinjau dari konsep keadilan dalam pendidikan multikultur. Kesetaraan dan keadilan yang merupakan landasan normatif pendidikan multikultur juga telah dijelaskan dalam al Qur'an Q.S alA'raf: 181,

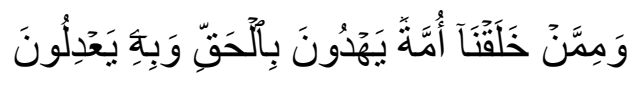

Terjemahnya:

"Dan di antara orang-orang yang Kami ciptakan ada umat yang memberi petunjuk dengan hak, dan dengan yang hak itu (pula) mereka menjalankan keadilan"

Karakteristik keempat yakni mengakui dan menghargai HAM. Selanjutnya mengenai karakteristik mengakui dan menghargai Hak Asasi Manusia baik sebagai individu maupun sebagai anggota suatu kelompok dalam masyarakat. Menurut Tilaar (2002) prinsipprinsip dasar yang menjadi acuannya dalam rinsip pendidikan multikultur adalah $p$ pengakuan terhadap hak azazi manusia (HAM), asusmi dasar dari prinsip ini adalah bahwa proses pendidikan adalah untuk merealisasikan HAM. Sementara dalam prespektif pendidikan Islam HAM mendapat posisi yang tinggi. Hal ini terlihat dari prinsip dasarnya sebagai implikasi dari ciri manusia, pendidikan Islam. melihat bahwa manusia adalah mahluk yang memiliki kebebasan berkehendak. Manusia mempunyai karakteristik kebebasan berkehendak, kemauan untuk memilih dan memutuskan tingkah lakunya sendiri. Kebebasan manusia meliputi berbagai dimensi seperti kebebasan beragama, berbuat, mengeluarkan pendapat, memiliki, berpikir, berkreasi dan lain sebagainya. Firman Allah SWT dalam surat al-Baqarah : 256

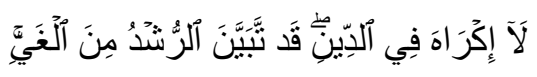


Terjemahnya:

"Tidak ada paksaan untuk (memasuki) agama (Islam);

Sesungguhnya telah jelas jalan yang

benar daripada jalan yang sesat.

Penghargaan atas hak asasi manusia didasarkan pada paradigma memandang hakikat manusia mahluk dengan segala inividualitasnya merupakan masing-masing yang memiliki ciri khas tersendiri berdasarkan potensi-potensi yang dimilikinya. Walau manusia diberi kebebasan tetapi kebebasan iu tidak mutlak di mana ia sanggup berbuat semaunya. Kebebasan dalam Islam adalah kebebasan yang terikat oleh rasa tanggungjawab, tidak menghalangi kebebasan orang lain, nilai- nilai agama dan moral yang dianut masyarakat, undangundang yang berlaku, kebersamaan dan keadilan serta akal logika.

Dalam kaitannya terhadap HAM, relevansi antara pendidikan multikultural dengan pendidikan Islam ialah keduanya memberikan penghargaan yang tinggi serta jaminan bagi setiap individu, maka sangat salah besar jika menganggap bahwa pendidikan Islam tidak humanis. Justru Islam sangat menghormati hak asasi manusia sebagai mahluk Tuhan dengan pembatasanpembatasan tertentu untuk menjaga agar manusia tetap terlindungi hak-hak asaasinya secara proporsional karena pendidikan Islam juga tidak meluputkan diri pada satu hal dan mementingkan yang lain terlepas adanya perbedaan suku, ras, dan agama.

Pengakuan terhadap perbedaan menjadi hal yang sangat diutamakan dalam prinsip multikultural. Pengakuan Hak Asasi Manusia sebagai individu maupun kelompok memperoleh posisi yang penting dan strategis dalam paham multikulturalisme. Dalam multikulturalisme kesadaran akan keragaman budaya yang mencirikan keunikan dan keunggulan sekelompok masyakat pada muaranya melahirkan konsep, pemikiran, pemahaman mengenai toleransi, kesetaraan, keadilan, kebersamaan, dan perdamaian. Paham inilah yang lebih lanjut memiliki tujuan untuk menciptakan sebuah kehidupan yang aman, tentram, damai dan sejahtera dan terhindar dari konflik yang berkepanjangan.

\section{b. Tantangan Pendidikan Islam}

\section{Multikultur di Indonesia}

Pendidikan Islam sebagai sub bagian dalam sistem pendidikan nasional, dituntut untuk dapat menginternalisasikan nilai dan konsep multikultural ke dalam proses pendidikan Islam. Meskipun demikian, penerapan paham multikulturalisme pada setiap komponen dan bagian dari sistem pendidikan Islam bukanlah hal yang mudah untuk dilakukan. Dalam praktiknya hambatan, rintangan dan tantangan muncul pada setiap tahapan proses pengimplementasiannya. Banyak pertimbangan dan kesukaran dalam wacana 
perumusan mengingat bahwa pendidikan Islam yang dilandasi multikultaralisme bukanlah sesuatu dengan jaminan kepastian sukses, butuh kerja keras dan perjuangan yang panjang untuk mewujudkannya.

Adapun tantangan dan hambatan yang menjadi bahan pertimbangan dalam merumuskan dan mengadopsi paham multikulturalisme dalam dunia pendidikan Islam, diantaranya:

\section{Perbedaan}

akan multikultural sebagai

\section{Ideologi}

Paham multikulturalisme mengutamakan pengakuan terhadap perbedaan dan hak asasi manusia. Keragaman setiap individu maupun kelompok memperoleh posisi yang terhormat dalam pandangan multikulturalisme terlepas apapun bentuk dan keunikannya. Dalam wacana pendidikan, landasan ideologi pendidikan multikultur ialah mengakui adanya perbedaan, menghargai kesederajatan tanpa membedakan, dan menghormati keragaman baik suku, ras, dan agama.

Pandangan yang menganggap bahwa keragaman agama sebagai bagian/ produk budaya memiliki nilai kebenaran dan derajat yang sama tentu tidak dapat diterima oleh smua penganut agama. Kesepakatan untuk menerima dan mengakui keragaman agama sama halnya mengakui bahwa ternyata ada kebenaran lain di luar kebenaran agamanya. Konsep yang mengakui adanya keragaman budaya dengan derajat kebenaran yang sama inilah yang selanjutnya menjadi begitu penting dan krusial dalam pandangan Islam.

Menurut Muhammad Yahya (2010) bahwa berkembangnya paham yang mencampuradukkan antara keragaman dan keagamaan akan mendorong terjadinya pengikisan nilai-nilai ritual dan kesakralan agama secara perlahan. Mengutip pandangan John Elposito (Yahya, 2010) bahwa multikulturalisme dan pluralisme disinyalir memiliki dampak terhadap sistem keyakinan suatu komunitas muslim. Pengakuan terhadap keragaman yang terdapat dalam agama lain dapat melemahkan sistem keyakinan umat Islam.

Multikulturalisme ditawarkan melalui berbagai cara yang mudah diakses oleh generasi muda telah membentuk kepasrahan dan pemakluman untuk menerima budaya lain yang sebenarnya dapat merusak keyakinan terhadap kaidah agama. Ince $\mathrm{N}$ (2018) melalui wawancara menyatakan promosi melalui internet, berita di televisi, film, dan media massa lainnya, memberikan sumbangsi dan pengaruh signifikan dalam membentuk pola pikir anak remaja, anak yang sering melihat remaja seusia mereka tidak menutup aurat pada akhirnya akan memaklumi bahwa mengumbar aurat dengan 
berpakaian minim bukanlah suatu hal yang tabu dan dilarang oleh agama.

Pada akhirnya, perbedaan pemahaman akan landasan ideologi inilah yang kemudian menjadi hambatan internalisasi paham multikulturalisme dalam pendidikan Islam.

2. Kecenderungan ekslusifitas pada kelompok homogen.

Fenomena homogenisasi sering diterjadi dalam dunia pendidikan. Dalam praktinya dilapangan terdapat satuan pendidikan baik pendidikan dasar, menengah maupun tinggi yang latarbelakang sosial, ekonomi, etnis dan agama yang cenderung homogen. Setiap hari anak-anak bergaul dan berinteraksi hanya dengan teman segolongan mereka saja. Jika keadaan ini terus berlanjut diluar maka pengalaman anak untuk memahami dan menghargai perbedaan akan rendah.

Keberadaan pasal yang mengatur pendidikan agama dalam UU No 20/2003 membuat sekolah berafiliasi agama merasa enggan menerima siswa tidak seagama. Hal ini membuat pengelompokan anak berdasar agama saja, selanjutnya dalam pergaulanpun mereka cenderung bergaul dengan yang memiliki kesamaan latarbelakang, baik sosial, ekonomi, ras dan etnis.

Fenomena homegesasi ini tentu menjadi penghambat dalam penerapan pendidikan Islam multikultur.

\section{Ambigunya batasan toleransi berpotensi pada ego-sentrisisme.}

Pendidikan Islam diarahkan untuk dapat mengantarkan individu bersikap toleran, menghargai nilai-nilai kemanusiaan, dan suka pada perdamaian. Nilai-nilai toleransi sangat dibutuhkan untuk terciptanya masyarakat yang bercirikan universalitas, supremasi hukum, menghargai perbedaan, kebaikan dari dan untuk semua, meraih kebajikan umum, dan menjunjung tinggi harkat dan martabat manusia. Akan tetapi, permasalahan selanjutnya muncul diakibatkan ambigunya batasan akan toleransi. Toleransi yang kebablasan justru akan mengantarkan pada inkonsistensi umat dalam menjalankan ajaran agamanya dan memunculkan ego-sentrisisme, sikap yang mentoleransi hal lain demi dirinya sendiri atau sikap acuh tak acuh.

Hal ini tentu menjadi hambatan dan tantangan bagi pendidikan Islam, mengingat bahwa konsep toleransi yang tidak jelas garis batasnya justru akan berdampak pada inkonsistensi dalam menjalankan agamanya.

\section{Pemilihan model dan jenis multikultur yang cocok untuk Pendidikan Islam}

Hambatan dan tantangan implementasi pendidikan Islam multikultur juga ditemui dalam pemilihan model konsep yang cocok untuk bangsa Indonesia. Menurut Parekh (2010), setidaknya terdapat tiga model 
kebijakan multikultural negara-negara di dunia yakni model nasionalis, nasional etnis dan multikltural etnik. Setiap model memiliki kelebihan dan kekurangan masing-masing. Dengan melihat karakteristik ketiga model multikultural tersebut, dinilai tidak tepat untuk diterapkan di Indonesia. Model pertama tidak dapat diterapkan karena adanya kecenderungan menyampingkan etnik-etnik yang seharusnya tetap eksis dan berkembang, model kedua rawan dengan xenophobia dan diskriminasi antar etnik dan model ketiga rawan memunculkan konflik dari kebijakan negara yang bias. (Ismail fuad, 2009)

Selain tiga model yang diajukan Parekh, terdapat lima model multikulturalisme lain yang diterapkan yakni (1) multikulturalisme isolasionis, multikulturalisme akomodatif, multikulturalisme otonomis,

Multikulturalisme kritikal atau interaktif, (5) Multikulturalisme cosmopolitan. Kelima model multikultur tidak cocok untuk diterapkan di Indonesia. Penyelenggara pendidikan Islam memerlukan usaha lebih untuk menyaring dan mempertimbangkan dengan bijak jenis multikulturalisme yang tepat atau paling tidak mendekati tujuan meminimalisir konflik horizontal.

5. Kelayakan dan kesiapan setiap komponen-komponen dari sistem pendidikan Islam
Pendidikan Islam di Indonesia masih dihadapkan dengan berbagai macam permasalahan pada setiap aspek dan komponennya. Berbagai hambatan mulai dari masalah dana, sumber daya manusia, sarana prasarana, sampai pada tingkat tenaga ahli kerap dijumpai dalam upaya pembaharuan pendidikan Islam. Secara ideal, Lembaga pendidikan Islam diharapkan mampu menjawab tantangan modernisasi dan globalisasi serta mampu mengambil peran dalam pemenuhan fungsi untuk mempelajari ilmu umum dan ilmu agama serta keterampilan. Tetapi dalam praktiknya di lapangan, mengakibatkan beban kurikulum yang terlalu banyak dan cukup berat dan bahkan tumpang tindih. Hal ini pada akhirnya menambah kerumitan ketika konsep multikulturalisme juga akan di internalisasikan dalam pendidikan Islam, yang mana bentuk kurikulum dari pendidikan multikultur merupakan hidden curiculum atau kurikulum yang tidak tertulis utuh dalam suatu bentuk tetapi nilai-nilai yang diinternalisasikan.

$$
\text { Komponen selanjutnya ialah }
$$
sumberdaya manusia dalam hal ini pendidik dan tenaga kependidikan. Kelayakan dan kompetensi SDM pada satuan pendidikan Islam di Indonesia memang terus ditingkatkan dengan berbagai cara. Akan tetapi, pembekalan dan peningkatan kompetensi untuk mengelola pembelajaran 
multikulturalisme dinilai masih kurang. Hal ini sesuai dengan pernyataan Ali D (wawancara, 2019) bahwa pemberian pelatihan dari pemerintah sudah sangat banyak dan bervariasi, akan tetapi yang khusus pengelolaan pembelajaran berbasis multikultural itu sangat sedikit itupun biasanya membaur dengan pelatihan lainnya. Dalam hasil penelitian Nuraliah A (2018) menyatakan bahwa karakteristik pendidik memegang peranan penting dalam pengelolaan pembelajaran. Latar belakang dan wawasan pendidik yang luas akan mampu memberikan pembelajaran yang variatif.

Ketidaksiapan juga terlihat dari materi konten buku-buku teks Agama. Materi pluralitas, keragaman, multikultur dan kemajemukan biasanya ditemukan dalam buku pendidikan kewarganegaraan atau pendidikan moral pancasila. Muatan materi multikultural masih sangat jarang ditemui dalam satu komponen utuh materi pendidikan Islam.

\section{c. Peluang Pendidikan}

Multikultur di Indonesia

Dalam upaya membangun Indonesia, Konsep dan ide multikulturalisme menjadi isu strategis dan keputusan bijak dalam menyikapi kultur Indonesia yang beragam. Indonesia merupakan bangsa yang lahir dengan multikultur dimana kebudayaan tidak bisa dilihat hanya sebagai kekayaan yang dibanggakan tetapi harus ditempatkan berkenaan dengan kelangsungan hidup sebagai bangsa. Maka lebih lanjut dalam bidang pendidikan, konsep internalisasi nilai multikultural merupakan suatu keharusan dan tuntutan yang tidak dapat ditawar lagi.

Secara teoritis konsep multikultural sangat cocok untuk digunakan sebagai landasan untuk menjiwai kebijakan suatu negara yang mempunyai keanekaragaman seperti Indonesia. Keragaman budaya, suku, ras, etnik, bahasa dan agama dapat diakomodir melalui konsep yang dijiwai oleh multikulturalisme agar keragaman tersebut menjadi suatu aset yang bernilai, bukan justru menjadi sumber masalah dan konflik yang panjang. Mengingat pentingnnya pemahaman multikulturalisme dalam membangun kehidupan berbangsa dan bernegara yang damai, harmonis, menjunjung tinggi nilai kemanusiaan maka pendidikan yang dijiwai oleh multikulturalisme perlu dikembangkan.

$$
\text { Pengembangan pendidikan }
$$

Islam multikultur merupakan proses yang sangat penting bagi kelangsungan sejarah kebudayaan setiap tradisi sebuah bangsa, bahkan tradisi agama tertentu. Mengalihkan kebudayaan dari generasi ke generasi melalui pendidikan merupakan proses yang sangat penting bagi kelangsungan sejarah, budaya, tradisi bangsa dan agama. Oleh karena itu, pengembangan pendidikan berbasis 
multikultur memiliki peluang yang besar multikultur ini adalah toleransi, anti untuk dikembangkan di Indonesia yang diskriminasi, penyelesaian konflik dan memiliki karakteristik yang multikultur.

Dalam konteks pendidikan Islam, mediasi, HAM, demokratis, pluralitas, multikulturalisme merupakan pilihan dan resiko yang perlu diambil agar dapat bersaing dimasa depan dan sekaligus resiko yang perlu diambil di dalam membina masyarakat madani demi menjaga kelangsungan tradisi dalam agama Islam. Multikulturalisme adalah keniscayaan yang tak bisa ditolak di Indonesia. Amin Abdullah (2005) berpendapat bahwa menafikan keberadaan tradisi-tradisi agama di muka bumi, baik di Barat apalagi di Timur, merupakan pekerjaan yang sia-sia. Karena itu, pendidikan yang mengacu kepada trans etnik dan agama harus diusung sedemikian rupa agar tercipta relasi yang dinamis dan harmonis. Oleh karena itu, pengembangan pendidikan Islam berbasis multikultur merupakan peluang yang perlu direspon dengan bijak dalam dunia pendidikan Islam.

Pengembangan pendidikan Islam berbasis multikultur merupakan respon dan jawaban akan tantangan modernisasi, globalisasi serta menjadi salah satu solusi dari banyaknya konflik dan keteganganketegangan bermotif SARA di Indonesia. Konflik etnis agama, penistaan agama, radikalisme agama, sparatisme, dan disintegrasi bangsa dapat dihindari karena nilai dasar dari konsep pendidikan kemanusiaan universal dan subjek-subjek lain yang relevan. Seiring dengan terus bergulirnya arus demokratisasi dalam kehidupan bangsa, yang berimplikasi pada penguatan civil society dan penghormatan terhadap hak asasi manusia (HAM) maka wacana tentang pendidikan Islam multikultural terus mengemuka.

Peluang nilai-nilai multikultural untuk dapat diimplementasikan dalam pendidikan Islam masih sangat terbuka berdasarkan adanya relevansi nilai-nilai pendidikan multikultural yang terdapat dalam pendidikan Islam. Selanjutnya, implementasi pendidikan Islam multikultural dapat diwujudkan tidak hanya terbatas pada ranah pendidikan formal saja, tetapi dalam pendidikan nonformal juga dapat diterapkan, keluarga maupun lingkup masyarakat yang lebih luas. Tentunya dengan proses yang panjang dan berkesinambungan disamping juga dengan perbaikan pada setiap komponen-komponen penyusunan system yang lebih komperhensif seperti kurikulum, sarana-prasarana, model pembelajaran hingga kompetensi pendidik harus disesuaikan dengan tujuan pendidikan Islam Multikultur. 


\section{KESIMPULAN}

Konsep mengenai relevansi antara pendidikan Islam dan pendidikan multikultur dapat dilihat dengan menyandingkan konsep, ide, pemikiran diantara keduanya. Karakteristik pendidikan Islam dan multikultural dapat dipahami bahwa ada kesesuaian antara nilai-nilai multikultural dengan nilai-nilai pendidikan dalam perspektif Islam seperti demokrasi, toleransi, keadilan, kesetaraan, menghargai perbedaan dan menjungjung hak asasi manusia. Meskipun demikian, sember kebenaran dari nilai-nilai multikultural tersebut berbeda. Jika nilai-nilai multikultural yang berasal dari barat bersumber dari filsafat dan bertumpu pada hak-hak asasi manusia, maka nilai-nilai multikultural dalam perspektif Islam bersumber dari wahyu.

Adapun tantangan dan hambatan yang menjadi bahan pertimbangan dalam merumuskan dan mengadopsi paham multikulturalisme dalam dunia pendidikan Islam adalah ketidaksamaan persepsi akan batasan multikultural sebagai sebuah
Ideologi, ambigunya batasan toleransi yang berpotensi pada ego-sentrisisme, pemilihan model dan jenis multikultur yang cocok untuk bangsa Indonesia, kecenderungan ekslusifitas pada kelompok homogen, elayakan dan kesiapan setiap komponenkomponen dari sistem pendidikan Islam.

Meskipun terdapat hambatan dalam setiap tahapan proses, pengembangan pendidikan Islam berbasis multikultur memiliki peluang yang besar untuk dikembangkan di Indonesia yang memiliki karakteristik yang beragam. Peluang nilainilai multikultural untuk dapat diimplementasikan dalam pendidikan Islam masih sangat terbuka berdasarkan adanya relevansi dan inherensi pendidikan multikultural yang terdapat dalam pendidikan Islam. Pengembangan pendidikan Islam berbasis multikultur merupakan respon dan jawaban akan tantangan modernisasi, globalisasi serta menjadi salah satu solusi dari banyaknya konflik dan keteganganketegangan bermotif SARA di Indonesia.

\section{REFERENSI}

Abdullah, M. Amin. (2005), Pendidikan Agama Era Multikultural-Multireligius, Jakarta: PSAP.

Ahmadi, Abu. (2004), Sosiologi Pendidikan, Jakarta: PT Rineka Cipta.

Ali, N. A., \& Tanasy, N. (2018). Analisis Kinerja Guru PAI dalam Penerapan Metode Prompts pada Penyandang Disabilitas di SLB A Yapti Makassar. Inspiratif Pendidikan, 7(2), 207-218.

Azra, Azyumardi. (2005). Pendidikan Agama; Membangun Multikulturalisme Indonesia dalam Pendidikan Agama Berwawasan Multikultural, Jakarta : Gelora Aksara Pratama. 
Baidhawy, Zakiyuddin, Pendidikan Agama Berbasis Multikulturalisme, Jakarta: Erlangga, tt.

Choiri, Miftahul(2003), Pendidikan Multikultural dan Implementasinya dalam Pendidikan, Cendekia,3(2).

Gollnick, Donna M dan Phillip C. Chinn. (1998), Multicultural Education in a Pluralistic Society, edisi ke-5. New Jersey, Columbus: Merril an Imprint of Prentice Hall.

H.A.R. Tilaar.(2004), Multikulturalisme: Tantangan-tantangan Global Masa Depan dalam Transformasi Pendidikan Nasional, Jakarta: Grasindo. 2005. Manifesto Pendidikan Nasional; Tinjauan dari Perspektif Postmodernisme dan Studi Kultural, Jakarta: Kompas, Cetakan I.

Lexy, J dan Moleong.(1993), Metodologi Penelitian Kualitatif, Bandung : Remaja Rosdakarya.

Maarif, Syamsul.(2005) Pendidikan Pluralisme di Indonesia. Yogyakarta: Logung Pustaka.

Mahfud, Chairul. Pendidikan Multikultural. Yogyakarta: Pustaka Pelajar, 2006.

Maksum, Ali.(2011) Pluralisme dan Multikulturalisme Paradigma Baru Pendidikan Agama Islam di Indonesia. Malang: Aditya Media Publishing.

Maslikhah. (2007), Quo Vadis Pendidikan Mutikultural; Rekonstruksi Sistem Pendidikan berbasis Kebangsaan, Surabaya: JP Books.

Muhaimin.(2011) "Urgensi Pendidikan Islam Multikultural Untuk Menciptakan Toleransi dan Perdamaian di Indonesia" dalam Ali Maksum, Pluralisme dan Multikulturalisme Paradigma Baru Pendidikan Agama Islam di Indonesia. Malang: Aditya Media Publishing.

Mulkhan, Abdul Munir. (2005). Kesalehan Multikultural: Ber-Islam Secara AutentikKontekstual di Atas Peradaban Global, Jakarta: PSAP

Miles dan Huberman.(1992), Qualitatif Data Analysis. Tjetjep Rohendi Rohidi (penerjemah). Analisi Data Kualitatif. Jakarta: UI Press.

Ngainum Naim dan Ahmad Syauqi,(2008), Pendidikan Multikultural: Konsep dan Aplikasi, Yogyakarta: Ar-Ruzz Media.

Qaimuddin, S. (n.d.). Konsep Pendidikan Multikultural. Jurnal Al-Ta'dib.

Sangkot Sirait dalam Nizar Ali (eds.), Antologi Pendidikan Islam (Yogyakarta: Idea Press, 2010)

Sumartana, dkk., Pluralisme, Konflik dan Pendidikan Agama di Indonesia, (Yogyakarta: Pustaka Pelajar, 2001).

Suparta, Mundzier. 2008. Islamic Multicultural Education: Sebuah Refleksi atas Pendidikan Agama Islam di Indonesia, Jakarta: Al-Ghazali Center, Cetakan I.

Suseno, Franz Magnis, Memahami Hubungan Antar Agama di Indonesia, dalam Equality and Plurality dalam Konteks Hubungan Antar Agama, Yogyakarta: Sukses Offset, 2008.

Undang-undang tentang Sistem Pendidikan Nasional dan Peraturan Pelaksanaannya, (Jakarta: Sinar Grafika, 1993)

Zakiah Daradjat, Ilmu Pendidikan Islam, (Jakarta: Bumi Aksara, 2000) 